\title{
PLS Finance and Monetary Policy: A New Measure Mooted
}

\author{
Zubair Hasan*
}

Emeritus of Islamic Economics and Finance, INCEIF, Kuala Lumpur, Malaysia

\begin{abstract}
Islam banishes interest. This raises two questions contextual to Central Banking. First, can Islamic banks create credit like the conventional? We shall argue that Islamic banks cannot avoid credit creation; an imperative for staying in the market where they operate in competition with their conventional rivals. Evidently, the interest rate policy would not be applicable to them as a control measure. This leads us to the second question: What could possibly replace the interest rate for Islamic banks? In reply, the paper suggests what it calls a leverage control rate (LCR) as an addition to Central Banks' credit control arsenal. The proposed rate is derived from the sharing of profit ratio in Islamic banking. It is contended that the new measure has an edge over the old fashioned interest rate instrument which it can in fact replace with advantage. It can possibly be a common measure in a dual system.
\end{abstract}

Keywords: Central banking, Credit creation, Leverage Control Rate (LCR), Islamic banks, Profit sharing.

\section{INTRODUCTION}

This paper deals with an aspect of monetary policy in a dual financial system where the Islamic and mainstream financial institutions operate side by side in a competitive setting. The policy addresses a number of objectives including the mobilization of resources for development, promotion of distributional equity and maintaining stable the internal and external value of domestic currency. However, we shall presently be looking at monetary policy contextual to credit control measures a Central Bank employs to mitigate volatility in macroeconomic variables. Such volatility often promotes the proclivity to crises that snowball to inflict severe injuries on national economies across the globe. The 2007-2010 turmoil is the recent example.

Such an exercise needs a prior relook on the process of credit creation and its regulation, especially because one cannot ignore the recent emergence and phenomenal growth of Islamic banking across the globe; in 90 countries- developed and developing Islamic banks operate in competition with the conventional. Thus, in finance, the expansion of what one may call a dual banking system is on the rise. The scenario raises some ticklish questions that have to be answered prior to discussing the stability issue, the focus of this paper.

Required is the discussion on three issues. One, since sharing of profit ratio replaces interest rate in Islamic banking, how would this ratio be determined? Two, can or should Islamic banks be allowed to create credit the same way as do the conventional? Third, if

*Address correspondence to this author at the Emeritus of Islamic Economics and Finance, INCEIF, Kuala Lumpur, Malaysia; E-mail: zubair@inceif.org, zubhasan@gmail.com

JEL codes: E51 and E52. yes, how could this ratio be controlled and to what effect? It is in answering this last question that the paper presents a new instrument for consideration of the learned.

Thus, Section 2 of the paper briefly deals with the need for and the process of credit creation. Section 3 highlights the linkage between profit sharing and return to capital. In Section 4 we explain the proposed instrument for credit control and unveil its ramifications. Section 5 contains a bit of digression, relevant though. It discusses the connection between risk, profit and finance to arrest amis leading tendency of providing prosthetics to rivet risk-sharing as the sole principle of Islamic finance. ${ }^{1}$ Finally, Section 6 contains a few concluding observations.

\section{CREDIT CREATION PROCESS}

Capitalism not only presupposes the existence of hired factors of production - workers and the natural resources - in the economy but also of an initial facility of finance provided by bank credit to pay for circulating capital including wages. The recent heterodox view that finance is a sort of invisible ex ante flow in modern economies has elements of truth; it links well with Keynes (1930) according recognition to the importance of money as financial asset. The recognition led to viewing money as an interest bearing claim the banks could create or destroy at will in response to variations in the demand for money (liquidity) even though it carried no intrinsic value.

Islamic banks operate in a capitalist system in competition with their conventional counterparts. They

\footnotetext{
${ }^{1}$ The latest example pro-motives of such discussions is Nabil and Mirakhor (2015). For a critical appraisal of the literature on risk-sharing in Islamic finance, see (Hasan 2015).
} (C) 2016 Lifescience Global 
cannot do business in defiance of the systemic requirements. They can possibly observe the Islamic ban on interest but would find survival threatened without credit creation. Fractional reserve system is a pre-requisite for credit creation. Hence, suggestion of keeping $100 \%$ reserve against deposits in Islamic banking is impracticable. It would thus be helpful to see briefly how banks create credit to understand and evaluate measures the Central Banks use for controlling it to keep the system stable.

How the fractional reserve system enables banks to create money is easy to see. Initially banks have cash deposits. Each bank knows by experience that on a normal day most people withdraw only a fraction in cash from their accounts. So, retaining a safe fraction of cash deposits, the bank lends the rest to a third party on interest. But it asks the borrower to open an account with the bank to deposit in the loan money. Thus, loans create deposits, appearing on the opposite sides of its balance sheet. The bank treats credit deposits as cash deposits and advances loan out of loan so to say. The process multiplies deposits raising an inverted loan pyramid. Suppose each bank retains on an average $F$ fraction of cash deposits as reserve to meet the daily withdrawals while the Central Bank of the country wants banks to maintain with it a minimum fraction $R$ of their deposits (cash + credit) in the form of cash. How much credit can a bank create given these constraints? The credit multiplier $\mathrm{k}$ provides the answer. Ignoring proof, $\mathrm{k}$ can be calculated as:

$k=\frac{1-R}{F}$

Note that an individual bank cannot create credit disproportionate to others in the system because on balance it will soon find its net cash inflows reducing via inter-bank clearances. The cash string forces it to remain with the group. However, the credit creation power of the banking system as a whole is tremendous as mutual claims largely cancel out against each other. For the banking system as a whole, the causality tends to move from bank credit to deposits; not the other way round. Banks are not a "cloakroom". Given the institutional framework of free markets, the banking system can meet any demand of business for credit at the current rate of interest the banks unilaterally determine (Egmont 2012, 2). The interest received on this huge amount minus the part of it payable to cash depositors and other operating expenses, all belong to the bank owners which they share with their managers and agents.
Banking is thus an exceedingly lucrative business. Maturity transformation via renewals converts shortterm funding into the long-term. Leverage gains tend to make businesses over-adventurous. Rising profit margins ${ }^{2}$ lure banks continue pumping in the air until the balloon bursts, economies roll down the hill; unemployment becomes rampant. Rising leverage gains fuel greed and have largely been the cause of frequent financial turmoil like the one world faced after 2007. The solution is seen in raising the capital coverage of borrowings for restraining credit expansion beyond the limits of safety. Standard capital adequacy ratios are being developed under what are known as Basel Accords ${ }^{3}$. However, evidence is mounting to show that minimum capital requirements like the tier capital ratio - the CAR -are having little success in reducing the risk of bank failures (Nowak 2011, 3).

If the credit creation tends to fuel leverage lure causing injurious fluctuations in the economy, why not ask banks to keep with them all time the legal tender (base) money people deposit with them? This is the same as the insistence of Islamic economists on a $100 \%$ reserve system instead of the fractional. Of late, one hears some supporting voices in the mainstream economics as well. To me, that is neither operable nor expedient. The demand for a $100 \%$ reserve must create rigidity in money supply response to the genuine seasonal ups and downs in money demand; it may even result in as much trouble if not more as the current fractional system unleashes.

One compelling reason for allowing banks to operate on the fractional reserve basis is that the act facilitates the adjusting of money supply to seasonal demand variations. Figure 1 shows how credit creation keeps demand for money commensurate with normal base money supply in the economy (Hasan 2014, 4243). Thus, credit creation is an economic imperative and Islamic banks need not be denied the option to

\footnotetext{
${ }^{2} \mathrm{~A} P \mathrm{PhD}$ research work of Nurhafizah Malim at INCEIF (2015) on bank-margins poses an interesting question: How should one interpret high/low bank margins? High margins benefit banks but at the same time they make financing expensive for the society and curb growth. Reverse would be the impact of low margins. How to build a trade off?

${ }^{3}$ For a critical evaluation of Basel Accords, see Hasan (2014). The Capital Adequacy ratio is found as under $\mathrm{CAR}=\frac{\text { Tier } 1 \text { capital }+ \text { Tier } 2 \text { capital }}{\text { Aggregate risk }- \text { weighted assets }} \geq 1$

Capital adequacy ratios are a measure of the amount of a bank's capital expressed as a percentage of its risk weighted credit exposures. An international standard which recommends minimum capital adequacy ratios has been developed to ensure banks can absorb a reasonable level of losses before becoming insolvent. Applying minimum capital adequacy ratios serves to protect depositors and promote the stability and efficiency of the financial system": Central Bank of New Zeeland.
} 


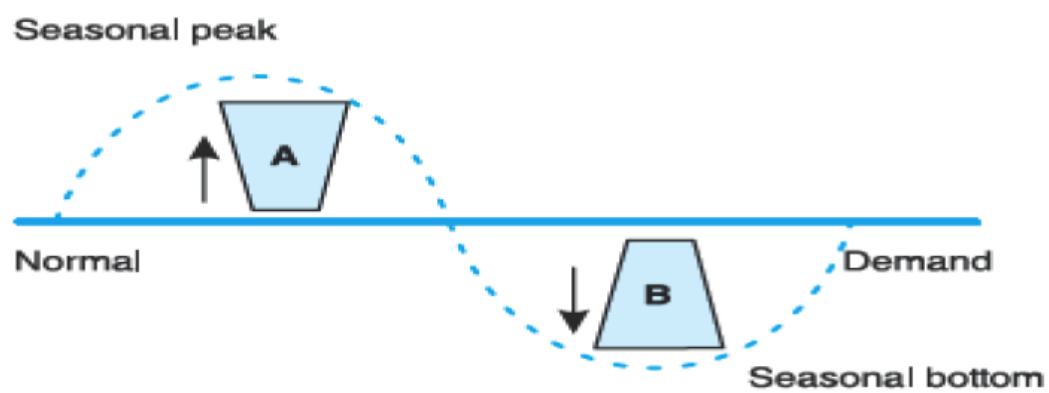

Figure 1: Normal base money supply and seasonal demand variations adjusted by credit money changes.

promote their survival. Anyway, they have had to fall in line with the global practices here also as elsewhere. Monetary authorities in various Muslim countries and the IFSB are seized with the issue: the regulatory frameworks are being revamped and new standards are being designed. Credit control has to be part of the exercise. As Islamic banks replace interest with profit rate, let us see how such a rate comes into existence.

In view of the absence of a precise price like the rate of interest in the conventional financing, the Islamic money market remains under developed and so is the case with contractual relationships between the Islamic system and the Central Bank that reduces refinancing facilities for the IBs. Until these weaknesses are overcome, credit creation and its advantages to the Islamic segment of the dual systems must stay below par. Indeed, the surplus liquidity anywhere in the Islamic system may have the proclivity of flowing into conventional banking.

These limitations and possibilities need be addressed. Contextually, one must note that for refinancing connectivity across countries a corporate facility -the International Islamic Liquidity Management (IILM)-is already in operation at Kuala Lumpur since October 2010. It has been founded by a diverse group of shareholders including Central Banks, monetary agencies as well as a multilateral institution the Islamic Corporation for the Development of the Private Sector ICD of Turkey. The issuance of short duration Sukuk at low profit rates in the international markets is the essential source the IILM uses for raising funds. ${ }^{4}$

\section{PROFIT SHARING AND RETURN ON CAPITAL}

Participatory finance is regarded as the high point of Islamic finance where losses are shared in the same ratios as the capital contributions of the parties but the

\footnotetext{
${ }^{4}$ See IILM website: iilm.com
}

sharing of profit arrangement is not to be the same. The interesting question then is how the sharing of profit ratio is determined? Of course, it is settled by negotiations between the parties. But there have to be some factors guiding the negotiations. Mudarabah is a contract in which a financier, say a bank, provides funds to an entrepreneur (firm) for investing in a business venture to share profits in an agreed proportion, losses falling on capital alone. ${ }^{5}$ This view implies what we may call a pure Mudarabah model where the financier is assumed to provide the entire capital to an empty handed entrepreneur; the model fits well even today to small partnership businesses to undertake specific projects. But the modern economic scene is dominated by large corporations that have long eclipsed small proprietary businesses in size and significance. Likewise, banks have almost completely replaced personal financing of the earlier era with institutional arrangements. What realistically fits the present situations is the model of what we can term as mixed Mudarabah, where the bank is an outside financier providing fund to running businesses on a profit sharing basis. Corporations operate mostly with their (owners) shareholders' money supplemented by bank finance, if need be. Banks mostly use customer deposits for providing finance to various sorts of borrowers - individuals, firms and public institutions.

Banks mostly employ the two-tier Mudarabah models to work as financial intermediaries. On the one hand they obtain deposits from the clients under profit (loss) sharing arrangements; on the other hand they finance clients using these deposits plus their own money under the same sort of profit (loss) sharing contracts. It is obvious that the sharing ratio of profit

\footnotetext{
${ }^{5}$ Paraphrasing Bank Negara Malaysia, Mudarabah is an agreement made between a party who provides the capital and the other - an entrepreneur who is thus enabled to carry out business projects on the basis of sharing profit in pre-agreed ratios. However, losses, if any, are borne solely by the provider of funds. Bank Negara Malaysia. http://www.bnm.gov.my/index.php?ch=174\& $\mathrm{pg}=469 \& \mathrm{ac}=383$
} 
with the depositors would be less than the sharing ratio with the borrowers, the difference being the banks' margin. The profit sharing ratio is a function of the rate or return on investment, the leverage ratio, rate of interest and risk premium (Hasan, 2010 and 2014). We shall show that the sharing ratio with the depositors can be used as a credit control measure by the Central Banks ${ }^{6}$.

\section{CREDIT CONTROL: THE PROPOSED INSTRUMENT}

\subsection{Financing in the Corporate Era}

In the classical view of Mudarabah the entrepreneur was an empty-handed person, the financier providing the entire capital. The business constituted a one off short-run project; the concept of a large sized running business requiring perennial investment, even as its owners could change overtime, was not there. The scenario today is totally different. Corporate businesses need large investments on a long-run basis; Mudarabah has to join in a participatory financing program. In such a program the bank as mudarib would mostly provide only part i.e. $\lambda$ fraction of total capital $\mathrm{K}$ invested in a business. Thus, borrowed amount of money $\mathrm{L}$ divided by $\mathrm{K}$ would equal $\lambda: \lambda=\frac{L}{K}$. Thus, $\lambda$ operates both as the loss sharing ratio for the bank and also as the leverage measure for the borrowing firms. The firm owners' portion in capital would thus equal $(1-\lambda) \mathrm{K}$. Of course, losses, if any, are to be shared between the firms and the bank in the same ratios as are their capital contributions i.e. $(1-\lambda)$ and $\lambda$, respectively.

In a two tier mixed Mudarabah, profit sharing applies to earnings that are allocable to the part of capital $\mathrm{K}$ a bank provides to the firm. Thus, if $\mathrm{P}$ were distributable profits, $\lambda P$ would be allocable to the bank, the pure financier. It is this part of profit which is the subject matter for sharing with the firm. Negotiations between the two lead to the decision that a fraction of this, say $\gamma^{*}$ will go to the bank and the remaining $\left(1-\gamma^{*}\right)$ the firm will retain for entrepreneurial services it rendered to make bank money earn a return. By applying the same mechanism of bargaining between bank and depositors, this will give to the bank a part of

\footnotetext{
${ }^{6}$ Central Banking made its appearance on the scene in a big way after the Great Depression of 1930 s to regulate the working of commercial banks, especially their credit creation power to keep economy stable. Many books and articles on Central Banking appeared in due course of time. But the subject faded out from the literature during the last 40 years. One comes across some good articles and the book of Faure (2015) on line has a good coverage on the functions and policies of the Central Banks. Islamic finance is of more recent origin and not much is available on the subject; Uzair (1982) and Zaidi (1987) are casually referred to.
}

the depositor's profit (see details in Illustration 2, Appendices). The fraction of profit $\lambda \mathrm{P}$ going to the bank $\gamma *$ could be equal to, more than or less than its loss sharing ratio $\lambda$. But the fraction $\gamma$ of total profit $P$ would always be less than each of $\gamma^{*}$. As $\gamma P=\gamma * \lambda P, \gamma=\gamma * \lambda$. Since both $\gamma *$ and $\lambda$ are less than 1 their product, $\gamma$ must be obviously less than either of them. The derivation of $\gamma$ allows the treatment of the ratio issue at the macro level and helps construction of models to show, as in equation (2), that profit sharing ratio (PSR) $\gamma$ is a function of four variables i.e. the expected rate of profit $\pi$ on capital $\mathrm{K}$, the proportion of borrowings $\lambda$ in $\mathrm{K}$, the market rate of interest $r_{i}$ and the risk premium ${ }^{7}$ or economic profit $\alpha$ (Hasan, 1985).

$\gamma=\frac{\lambda}{\pi}\left(r_{i}+\alpha\right)<1$

Equation (2) provides us with a common sense and useful link between the profit sharing ratio of the banks and the rate of interest in a dual monetary system. It follows from equation (2) that in a competitive setting the sharing ratio $\gamma$ for the bank at the macro level varies inversely with profit expectations $\pi$ and positively with the others determinants $\lambda, r_{i}$ and $\alpha$. Now, we change the explanation of these variables with reference to the Mudarabah contract between the banks and their depositors so as to forge a credit control measure for Islamic banks.

We assume $\pi$ to be the rate of profit on total capital $\mathrm{K}$ invested in business $(\pi=\mathrm{P} / \mathrm{K})$. The bank has $(1-\theta)$ and the depositors $\theta$ share in $\lambda \mathrm{K}$. Now, suppose the maximum leverage gain (in addition to the overall return on $\mathrm{K}$ ) the central bank allows to banks is $\beta$. We may call it the leverage control rate (LCR). The upper limit for return on bank investment, in business firms labelled $\mathrm{K}_{\mathrm{B}}=(1-\theta) \lambda \mathrm{K}$, would thus be no more than $(\pi+\beta)$, the remaining profit accruing to depositors on their investment $\mathrm{K}_{\mathrm{D}}=\theta \lambda \mathrm{K}$. From profit $\lambda \mathrm{P}$, the amount $(1-\theta) \lambda P$ would be allocable to the bank on its share $(1-\theta)$ in $\lambda \mathrm{K}$, but the bank will also get $(1-\theta)$ fraction of profit allocable to the deposits i.e additional $\theta \gamma * \lambda P$ through the Mudarabah system. The upper limit for return on bank investment share is defined by the ratio of the stochastic returns generated through Mudarabah to the specific capital of bank. We may combine the relevant variables to set up for the rate of return $R_{B}$ on banks' investment in mixed Mudharabah financing. To

\footnotetext{
${ }^{7}$ As $\alpha>0$, the expected rate of profit is greater than the interest rate of market.
} 
keep matters simple we assume that $Y^{*}$ is the same for both the tiers. We set upfor bank profit $\mathrm{P}_{\mathrm{B}}$ as under.

$\mathrm{P}_{\mathrm{B}}=(1-\vartheta) \gamma^{*} \lambda \mathrm{P}+\left(\vartheta \gamma^{*} \lambda \mathrm{P}\right) \gamma^{*}$

which reduces to

$\mathrm{P}_{\mathrm{B}}=\gamma^{*} \lambda \mathrm{P}\left[1-\vartheta\left(1-\gamma^{*}\right)\right]$

Return on bank investment $\vartheta \lambda \mathrm{K}$

$\mathrm{R}_{\mathrm{B}}=\frac{\gamma^{*} \lambda \mathrm{P}\left[1-\vartheta\left(1-\gamma^{*}\right)\right]}{(1-\vartheta) \lambda \mathrm{K}}$

$=\frac{\gamma \pi\left[1-\vartheta\left(1-\gamma^{*}\right)\right]}{(1-\vartheta) \lambda}, \quad \gamma=\gamma^{*} \lambda$

This return is constrained to be no more than $\pi+\beta$; thus we may set up

$\frac{\gamma \pi\left[1-\vartheta\left(1-\gamma^{*}\right)\right]}{(1-\vartheta) \lambda} \leq \pi+\beta$

The $\frac{\gamma\left[1-\vartheta\left(1-\gamma^{*}\right)\right]}{(1-\vartheta) \lambda}$ part of equation (4) may be called the profit multiplier $\mathrm{m}$ for the bank. For Illustration 2 it works as 1.25 . The profir rate on totla investment $\pi$ being $0.2, R_{B}=25 \%$.

The merit of the illustration 2 is that the equation (4) captures all the variables and the operation of LCR; the variable of control $\beta$ may force changes in any one or more of them allowing greater flexibility to the system with lesser ramifications compared to the interest rate mechanism.

Thus, $\beta$ can be a cost free policy variable that the central bank of a country can use for mandatory ex post adjustment of the PSR in Islamic finance to enforce fairness in the distribution of profits between the banks and the depositors.
The use of the instrument would also force banks to adjust their leverage ratios of equation (2) via $\theta$ to harmonize with changes in $\beta$, and the sharing ratio $\gamma$ will also adjust accordingly. For, the introduction of $\beta$ as the control variable into the picture would by definition affect $\alpha$ in equation (2) impacting in the process the size of $\gamma$ the banks' profit sharing ratio with businesses that is by making credit costlier or cheaper.

Let us put $\frac{\lambda}{\pi}=\mu$ as any constant. We now have a linear equation $\gamma=\mu r_{i}+\mu \alpha$ where $\mu$ being a constant with $\mathrm{T}$ as the slope. It sets up a positive relationship between profit sharing ratio $\gamma$ and the rate of interest plus $\alpha$ as shown in Figure 2. It follows that for the same $r_{i}$ the profit sharing ratio $\gamma$ may fluctuate with changes in leverage ratio $\lambda$ or profit expectation $\pi$ or $\alpha$ the risk premium. But it could also remain constant, if changes in $\lambda$ and $\pi$ take place in the same direction such that $\mu$ remains unchanged. We can now depict the equilibrium value for $\gamma$ the profit sharing ratio and its relationship with its determinants as in Figure 2. An implicit assumption here is that risk premium a remains constant.

The use of $\beta$ - the LCR - as a credit control measure in a dual financial system has several advantages over the traditional bank rate policy. Bank rate policy operates through the manipulation of the money-use price which conflicts with the Islamic ban on interest. In contrast, $\beta$ leaves interest rate untouched; it operates directly on profit margins of both the financiers and the borrowing businesses having a better psychological impact. Interest rate is a blanket measure. It affects borrowings for all purposes in equal measure relatively more urgent and socially desirable or frivolous. Possibly, using $\beta$ would prove more amicable to pursue discretionary credit allocation policies i.e. for selective control of investment channels. Finally,

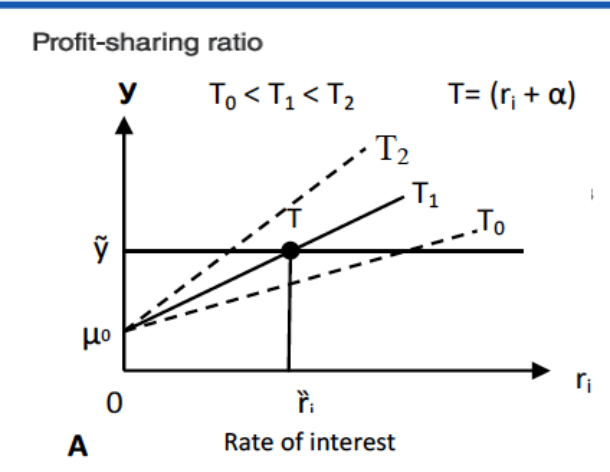

Capital

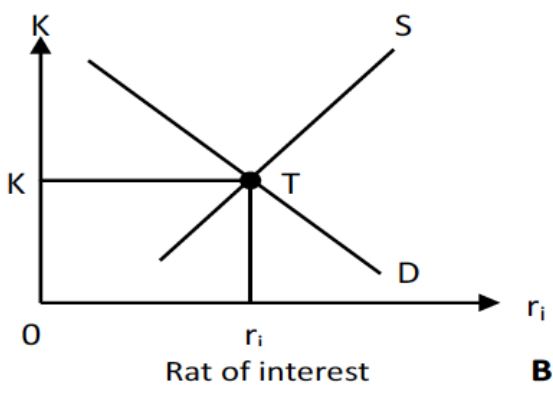

Figure 2: Profit sharing ratio in a state of equilibrium in Islamic Finance ${ }^{10}$. 
changes in interest rate affect the entire financing system - all purposes, all modes and all security markets restricting the frequency of using it. It forces upon the central Bank a loss inflicting open market operations regime. $\beta$ can be more flexible and selective; unlike the open market operations, it does not impose costs on the central Bank (Hasan, 2010).

\subsection{LCR and other Control Measures}

It is clear from equation 3 that ceteris paribus the profit sharing ration $\theta$ for the banks varies directly with $\beta$ the LCR in a linear relationship. And Figure 2 shows that rate of interest $r_{i}$ and $\theta$ too move in the same direction. Thus, a change in the LCR will tend to move the market interest rate to have similar results. The reverse is also true.

Of the other credit control measures Central Banks use the various reserve ratios are important. For example, all banking institutions - Islamic or conventional - have to maintain a Statutory Reserve Account with the Central Bank of the country. They have to keep a minimum proportion of their eligible deposits all the time in this account. This proportion is called the Statutory Reserve Ratio or the SRR. Lowering (raising) this ratio enables the Central Banks to expand (contract) credit in the economy. The measure is Shari'ah neutral. So is the case with statutory cash ratios that banks are required to maintain against time and current deposits. Moral persuasion too poses no problem.

The difficulty arises in the case of 'open market operations' as a measure for credit control. The Central Bank has to sell securities to mop up liquidity during inflation when prices of securities in stock with it are falling and has to buy them during the downturn when their prices are relatively high. Thus, in either case the Central Bank's ability to control credit would depend on how much loss it is willing to absorb. The LCR we have suggested helps avoid this dilemma.

\section{RISK, PROFIT AND FINANCE}

\subsection{Impact of Knight}

A primary attribute of competition is the tendency to annihilate economic profit (loss) and bring the prices of real goods and services to equality with their money costs of production. Economic theorists have therefore searched for the source of profit in what makes competition imperfect. Knight (1921) argued with conviction that it was uncertainty born of dynamic change that made reality depart from the ideal profitless state in an economy. Uncertainty breeds risk and divides the society into those who prefer to take risks in the expectations of large gains and those who want to avoid risks in favour of getting sure specific, even if smaller incomes. Risk-preference and riskaversion divided human beings into the hired and unhired production factors in all societies independent of time and space $^{8}$. Entrepreneurs, however defined, fall in the un-hired category. They guarantee fixed specific returns to the hired factors of production including lenders of money, workers and property owners - in the form of interest, wages and rent. Entrepreneurs choose to be claimants of the residual business earnings in the expectations of large gains but have to simultaneously expose their investment to the risk of shrinkage (loss) if revenue receipts belie expectations and fall short of payments due to the hired factors. This is how capitalism operates.

This inevitable division of people into hired and unhired factors knocks at the bottom of a plea now gaining currency in Islamic economics. It is being argued that risk-sharing could alone be the Islamic basis of pecuniary contracts. For, it is interest induced risk-transfer alone that has brought the world to the current chaos and would continue to do so unabated. To be sure, this is not a new plea. Only a new cloak is being wrapped around an old edict in classical origin: 'No risk, no gain' (Hasan 2005). ${ }^{9}$ No one disputes that participatory finance is in principle a more desirable rather preferred mode for financing - Islamic or conventional - without distinction. But projecting as being currently done that risk-sharing is the only principle acceptable to the Shari'ah, that conventional banks transfer all their risks to others is untenable, rather perilous. To the naivety of this line of argument we shall soon return.

\footnotetext{
${ }^{8}$ This view of Knight is perhaps too simplistic. Is it really uncertainty or lack of means to face uncertainty that plays dominant role in dividing people into the hired and un-hired production factors i.e. into risk takers and risk-averters? To me it looks more a question belonging to income and wealth distribution than of temperamental differences. De Kock 1939 becoming the most sought after. However, during the past 50 years not much is written on Central banking in general, though country studies proliferated.

${ }^{9}$ Presumably the connection is overdone by its proponents. Risk is neither commodity which the risk-taker offers to society nor labour he does on some material to claim compensation. It is purely a specific mental state that instills in him the fear of adverse consequences of an action. He must desist from the action if he cannot overcome the fear or he must conquer his fear and take the consequence. Hence it is entirely his discretion to act and if he does he must alone bear the consequence. Mastery over the fear of adversity is a great virtue both psychologically and morally; the society does needs such people. But a moral valuation is not the same thing as an economic valuation (Baqiras-Sadr, 1984, 75-76).
} 
The logic of capitalism not only presupposes the existence of hired factors of production - workers and the natural resources - but also of an initial facility of finance provided by bank credit to pay for wages. The recent heterodox view that finance is a sort of invisible ex ante flow in modern economies has elements of truth; it links well with Keynes (1930) according recognition to the importance of money as financial asset. The recognition led to viewing money as an interest bearing claim the banks could create or destroy at will in response to variations in the demand for money (liquidity) even though it carried no intrinsic value.

Islamic banks operate in a capitalistic system in competition with their conventional counterparts. They cannot do business in defiance of the systemic requirements; they can possibly observe the Islamic ban on interest but would find survival difficult without credit creation. Fractional reserve system is a prerequisite for credit creation. Hence, suggestions of keeping $100 \%$ reserve against deposits in Islamic banking are impracticable. It would thus be helpful to see briefly how banks create credit to understand and evaluate measures central banks use for controlling it to keep the system stable.

\subsection{Risk-Sharingand Islamic Finance}

The empirical evidence claiming that Islamic banks had faced the crisis better than their conventional rivals though dubious, contributed to the resuscitation of the old precept: 'no risk no gain' claiming that risk-sharing is the sole principle of Islamic finance. To us, the claim raises some serious questions. Does Islam disallow pre-fixed return on investment under all circumstance? Are sharing schemes entirely free of risk-transfer? Is risk-sharing always equitable? Or is interest-based financing entirely risk-free? Questions of the sort remain to be answered.

The claim under review is based on a rather restrictive interpretation of a leading Islamic maxim derived from a Prophetic tradition that says: 'Benefit goes with liability'10. The problem is the with the interpretation of the word 'liability' in the expression as the bearing of risk in financial transactions. ${ }^{11}$ Islam

\footnotetext{
${ }^{10}$ For a useful and detailed discussion on the maxim see Laldin $(2013$, 156160).

${ }^{11}$ Presumably, putting the maxim as 'benefit goes with liability to compensate' becomes better expressive of its import. It would also commensurate well with another Islamic maxim - legal permission negates liability. Candidly, the liability to bear loss in business cannot be abolished; it would go against the Islamic ban on interest. For details on the quoted maxim, see Laldin (2013, 164-166).
}

allows profit and loss sharing contracts among financing modes but not to the exclusion of others considered equally valid. Risk bearing is a consequence - not the cause - of such contracts. To put it straight, there is no such thing in Islam as a risk sharing contract which when entered into would result in the sharing of profit or loss. Liability in the maxim focuses on compensation, not on risk; forrisk is not a tradable commodity. Risk-taking per se cannot contribute to production; ownership of useful things including capital does. Equity of a profit share can be better judged with reference to capital investment not with reference to risk.

The contention finds support from another Islamic maxim, an inverse of that under discussion. It is derived from the Qur'an (2:275) "Those who swallow usury will not rise, except as someone driven mad by Satan's touch. That is because they say, 'Commerce is like usury.' But God has permitted commerce, and has forbidden usury. Whoever, on receiving advice from his Lord, refrains, may keep his past earnings, and his case rests with God. But whoever resumes-these are the dwellers of the Fire, wherein they will abide forever." that 'Liability accompanies gain'. There has to be a compensation. Thus, for a claim to profit, financier is liable to bear ex post loss not the ex ante risk.

Conventional finance is of course dominated by interest based transactions, but it is far from truth that it entails no risk-sharing. Equity holders share risk and equity dominates in long-term financing. Even when loans are advanced on interest bank face the risk of default and of adverse price movements in collaterals. That banks collapsed like house of cards in the current turmoil is evidence enough to see that interest-based finance is not always or entirely risk-free. Likewise, Islamic banks do transfer risk via hedging contracts. They also take collaterals to cove default risks. Bulk of transactions Shari'ah supervisors approve is debt based; participatory finance despite all effort and pleadings is still not popular. The valid distinction between Islamic and conventional finance is not that one is entirely risk-sharing and the other is entirely risktransferring; it lies in their proportion in the mix. ${ }^{12}$

Furthermore, it is not true that Islam bans risk transfer. It is a matter of interpretation. Banning interest

\footnotetext{
${ }^{12}$ It is interesting to note that some writers find Islamic finance inherently more risk-averse and thus holding the pace of economic development in Muslim countries; they produce evidence. In contrast, those who argue that it is in principle based on risk-sharing have nothing to show as testimony.
} 
does not imply an automatic ban on risk-transfer. Indeed, there is an argument that in pure classical Mudarabah where the worker/entrepreneur is emptyhanded the financier transfers a part of his risk to the worker. The financier does not make any payment to him in case of loss. He reduces his own loss equal to the transfer earnings of the worker; in a way risk is in part passed on to him (El-Gamal 2014, 1). Likewise, risk-sharing need not always be equitable, may be, it is rarely so. Risk being ex ante has no cardinal measure. The sharing ratio is a crude proxy for the division of profit. No one can demonstrate a one-on-one correspondence between the profit share of the parties and their risk exposures. Justice and fair play are the first requirement for calling something 'Islamic'. The difficulty is that tons of juristic writings analyzing contract forms provide little help to determine whether or not there is injustice in the exchange contract. Arbitrariness is the rule. ${ }^{13}$

\section{CONCLUSIONS}

We have examined the measures Central Banks can use to regulate credit creation from Islamic perspective and have suggested a new instrument based on the Islamic profit sharing norm. Its merit is that it can impact both categories of banks - Islamic and conventional - in the same direction without imposing costs on the Central Banks.

The year 2009 was a critical one for Islamic Finance as the downturn tested the resilience of the institutions and financing structures that endeavour to comply with the ethical and moral investment guidelines that form the core of the Shariah law. The crisis, however, showed that the sector has not been without its casualties, with high-profile Islamic names such as Tamweel, Amlak and The Investment Dar falling foul of the credit crunch (Howladar, 2010). Thus, the industry is likely to face increasing challenge in the future. Diversification, product innovation and the standardization of norms along with the harmonization of regulations across countries can go a long way to help Islamic finance industry face the impeding challenge.

Risk sharing in finance is not exclusive principle for Islamic finance. Fixed return rate on the stochastic

\footnotetext{
${ }^{13}$ The profit which the owner of a commodity obtains through its sale is based not on the risk involved but on the basis of the commodity proprietorship, even if the price (and profit) increases due to his transferring it to the market for ready availability to the consumers for he continues to remain its owner (Baqiras-Sadr 1984, 76).
}

earnings contracts are permitted as in Musharakah model based on moral and religious behaviour. On ground, they are much more in use than the sharing contracts. In fact their role in promoting growth and stability is dominant.

Islam stands for freedom of the individual and the markets but not at the cost of social well-being and fair play. The religion is not anti-rich and grants all protection to private earnings and wealth. But its norms of legitimacy are not a matter for market arbitration. State regulation of market behaviour and practices carries undisputed evidence over time and space in history. Islamic requirements for the fulfilment of basic needs, removal of poverty, reduction in inequities and keeping the balances straight in all spheres of life presupposes a substantial state intervention in the economic life of the community with discretion. Government intervention in economic activities is to be a source of stability, not of chaotic fluctuations under Islamic dispensation.

However, to pronounce ethical norms is one thing; to see them operate on ground is another. It would be far from truth to opine that conventional financial settings are devoid of ethical norms of behaviour; the lament is that it is the blatant and continual violation of these norms that has dragged the world to the brink of disaster in recent years.

\section{ACKNOWLEDGEMENT}

He gratefully acknowledges some valuable suggestions Professor Hassan B. Ghassan made for improvement to the original draft. He is also thankful for the help of his granddaughter Sadaf Rais in the preparation of this paper. The usual disclaimer, however, applies.

\section{APPENDICES}

\section{Illustration 1}

To illustrate, assume a bank has $\$ 50 \mathrm{~m}$ in cash deposits and has to keep $F=0.1$ fraction of the sum every moment in its safe to meet the daily withdrawal demands. Furthermore, suppose that each commercial bank is required to maintain $5 \%$ of its deposits -cash plus credit - in the form of cash with the Central Bank, implying that $R=0.05$. The credit multiplier $M$ will then be $10 \times 0.95=9.5$. The $\$ 50 \mathrm{~m}$ cash deposit with the bank will enable it to have a total deposit worth $50 \mathrm{x}$ $9.5=\$ 475 \mathrm{~m}$. If we take out $\$ 50 \mathrm{~m}$ cash deposits from the total, the remaining $\$ 425 \mathrm{~m}$ would be the credit-on- 
credit or loan deposits the bank has generated. The process creates an inverted pyramid of credit money which must of necessity be shaky; a narrow tip supporting a broad heavy top (Hasan 2014, 41).

\section{Illustration 2}

From equation (3) we get the maximum possible equilibrium value for the profit sharing ratio. It is obvious that for any given values of $\pi$ and $\lambda$ the profitsharing ratio $\gamma$ would vary directly with $\beta$. The relationship allows the Central Bank to use $\gamma$ as a cost-free instrument for credit control.

It is easy to see that the Central Bank of a country can lower $\beta$ to increase the rate of return to the depositors leading to a reduction in bank margins. To keep their margins intact the banks are expected to demand higher profit sharing ratio $\gamma$ from the borrowing firms reducing the leverage lure for profits. Thus, $\beta$ can be an effective control measure in the hands of a Central Bank to curb inflation. During recession an increase in $\beta$ could boost the sagging business morale through brightening profit expectations. Demand for investment funds may look up and credit creation may fill up the possible gaps.

We can find out in a given situation the leverage gain that is $\beta$ by inserting the relevant values in equation (3). If the Central Bank finds the margin too high, it may fix a lower $\beta$ as a control measure to dampen the leverage lure.

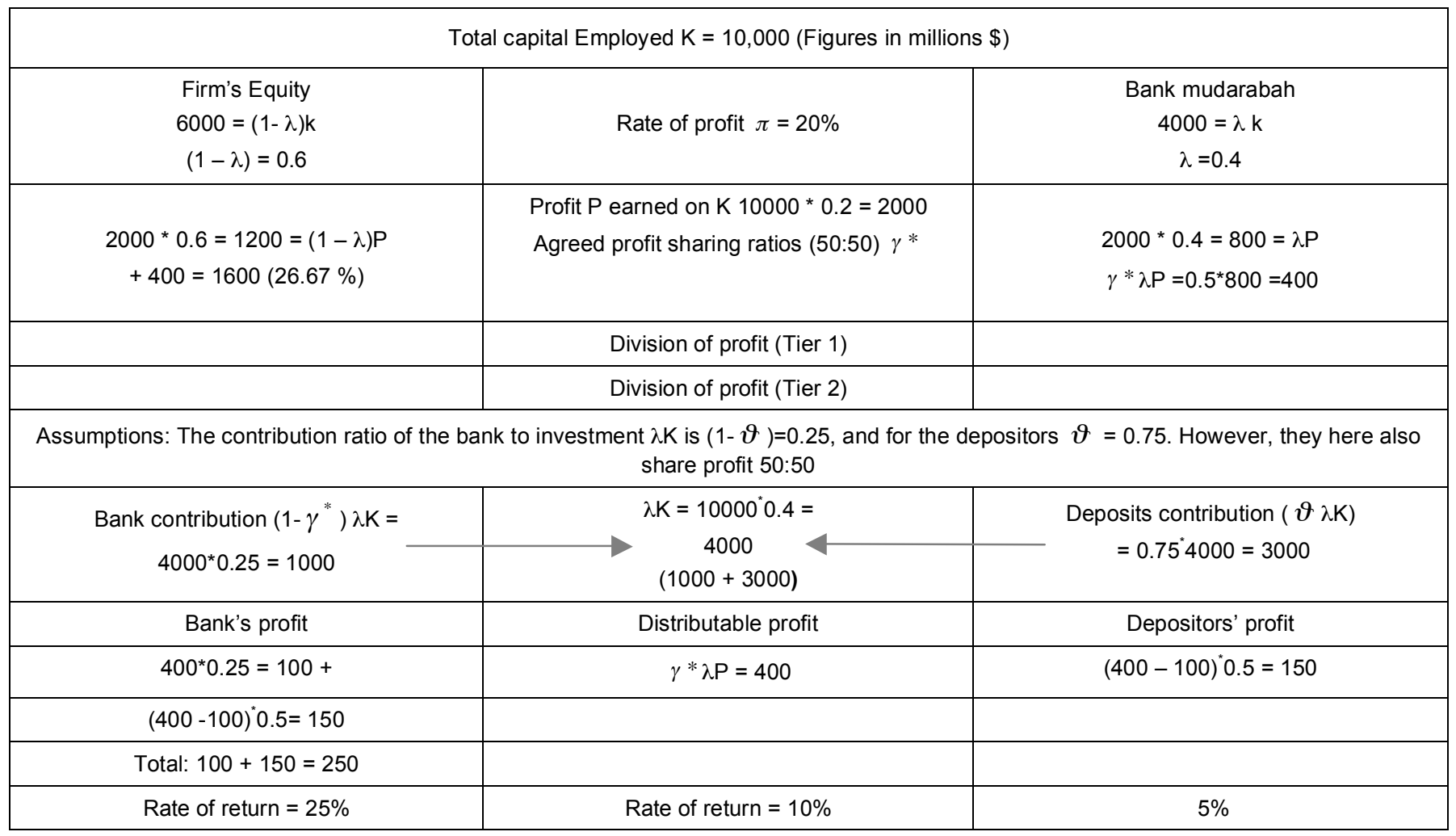

Note: The assumptions stated in the Table are to keep derivations simple. One can vary these assumptions to create intricate models.

\section{REFERENCES}

A. K. Malim, Nurhafizah. 2015. Bank Margins in OIC countries: Islamic and Conventional Banks Compared (Unpublished $\mathrm{PhD}$ dissertation)

Cihak, M. and Hesse, H. 2010. 'Islamic banks and financial stability: an empirical analysis', Journal of Financial Services Research 38:5-113. http://dx.doi.org/10.1007/s10693-010-0089-0

De Kock, M. Hendrik. 1939. Banks and banking, Central, P. S. King, UK pp.354
Egmont, KH. 2012. The emergence of profit and interest in the monetary circuit, University of Stuttgart, Institute of Economics and Law (On Line).

El-Gamal. 2014. Exploitative Profit Sharing: On the incoherence of all contract-based approaches to "Islamic finance "Accessed on 21/04/2014.

Faure, AP. 2015. Central Banking \& Monetary Policy: An Introduction bookboon.com

Hasan, M. \& Dridi, J. 2010. 'The Effects of Global Crisis on Islamic and Conventional Banks: A Comparative Study', IMF Working Paper 10/201. 
Hasan Z. 2015. Risk sharing versus risk transfer in Islamic finance: aCritical Appraisal. ISRA International Journal of Islamic Finance, Kuala Lumpur 7(1):xxx.

Hasan, Z. 2014. Basel Accords financial turmoil and Islamic banking. ISRA International Journal of Islamic Finance, Kuala Lumpur 6(1):xxx.

Hasan, Z. 2010. Profit sharing ratios in Mudarabah contract revisited'. International Journal of Islamic Banking and Finance 7(1):1-17

Hasan, Z. 2005. Islamic banking at the cross roads: theory versus practice, in lqbal, M, and Rodney, W (ed.) Islamic Perspectives on Wealth Creation, Edinburgh University Press

Hasan, Z. 1988. Distributional equity in Islam, in Iqbal M. (Ed.) Distributive Justice and need fulfilment in an Islamic economy, Islamic Foundation, UK

Hasan, Z. 1985. Determination of Profit and Loss Sharing Ratios in Interest-Free Business Finance, KAAU Journal of Research in Islamic Economics, Jeddah.

Higgs,Robert. 2012. Regime Uncertainty, Then and Now, [Online], Available: http://www.fee.org/the_freeman/detail/regimeuncertainty-then-and-now\#ixzz2M5ujJfFs

Howladar, K. 2010. 'Shariah risk: Understanding recent compliance issues in Islamic finance', Moody's Investor Service Report, p.1.

Received on 15-03-2016

Accepted on 20-03-2016

Published on 18-08-2016
Itani, Talal. 2012. This Quran could not have been produced by anyone other than God: The Quran. Published by Clear Quran, Dallas and Beirut. www.ClearQuran.com

Laldin, Akram et al. 2013. Islamic legal maxims \& their applications in Islamic finance, ISRA

Keynes, JM. 1930. 'A treatise on money'. New York: Harcourt, Brace and company.

Knight, FH. 1921. 'Risk, uncertainty and profit'. New York: Houghton Mifflin.

Nabil, MS., Mirakhor, A. 2015. Risk Sharing and Shared Prosperity in Islamic Finance. Islamic Economic Studies 23(2):xxx.

Nowak, R. Andreas. 2011. How Effective is Global Financial Regulation? The Basel Accords' Role in Mitigating Banking Crises,econ.duke.edu/uploads/assets/NowakRobert.pdf

Sadr, Baqir-as. 1984. Iqtisaduna (Our Economics, First Edition, Volume 2, English translation, World Organization for Islamic Services, Tehran, Iran.

Uzair, Mohammad. 1982. Central banking operations in an interestfree banking system. In M. Ariff (ed.), xxx.

Zaidi, NA. 1987. Profit rates policy for PLS depositors. Journal of Islamic Banking and Finance 4(4):35-46.

\section{DOI: http://dx.doi.org/10.6000/1929-7092.2016.05.25}

(C) 2016 Zubair Hasan; Licensee Lifescience Global.

This is an open access article licensed under the terms of the Creative Commons Attribution Non-Commercial License (http://creativecommons.org/licenses/by-nc/3.0/) which permits unrestricted, non-commercial use, distribution and reproduction in any medium, provided the work is properly cited. 